\title{
The Effect of Ball Diameter on Performance of Wet Scrubber with PVC Balls-Mesh Packing Material
}

\author{
Pathan Yasin ${ }^{1}$, Animalla Ramesh ${ }^{2}$, M.V Ramana ${ }^{3}$ and V.Rahul ${ }^{4}$ \\ ${ }^{1}$ Asst. Professor, CVR College of Engineering/ Mechanical Department, Hyderabad, India \\ Email: p.yasin339@gmail.com, \\ ${ }^{2}$ Asst. Professor, CVR College of Engineering/ Mechanical Department, Hyderabad, India \\ Email: ramesh.animalla@gmail.com \\ ${ }^{3}$ Professor, CVR College of Engineering/ Mechanical Department, Hyderabad, India \\ Email: ramlalith@rediffmail.com \\ ${ }^{4}$ Asst. Professor, CVR College of Engineering/ Mechanical Department, Hyderabad, India \\ Email: vudarahul@gmail.com
}

\begin{abstract}
Toxic pollutants and harmful flue gases resulting from combustion of fossil fuels in several industries are adversely effecting human and his environment. Packed towers, especially with wire mesh type mist eliminator pads are widely used to entrap these flue gas emissions before they enter into the atmosphere. But clogging of pads during the operation became a big problem which needs replacement with new one every time. The present work motivation is to develop and test, a exhaust fume-wet scrubber with new (PVC) balls-mesh replacing traditional packing material in which the spherical surfaces are going to make only point contact between them. Water $(\mathrm{PH}$ Value $=8.7)$ and lime water $(\mathrm{PH}$ Value $=12.3)$ sprinkled finely in modified air cooler body with 72 nozzles of $\mathbf{1 m m}$ in diameter and re-circulated for $\mathbf{1 0 0}$ minutes to purify stationary four stroke diesel engine exhaust. The diameter of the balls used, are varied such as $10 \mathrm{~cm}, 5 \mathrm{~cm}$ and $2.5 \mathrm{cms}$ and drain water samples, for every 20 minutes are collected to check $\mathrm{PH}$ values.
\end{abstract}

Key words: Packed towers, PVC balls-mesh, lime water, PH Value

\section{INTRODUCTION}

Man, and his environment can be affected by the combustion of fossil fuel. The emissions of fossil fuel include the pollutants such as fly ash, sulphur oxides nitrogen oxides, and volatile organic compounds. Combustion of fossil fuels are resources of generation of sulfuric, carbonic, and nitric acids, which falls to earth as acid rains, causes global warming, pollutes natural areas and corrodes buildings. When it comes to human beings, they can cause impaired lung function, shortness of breath, wheezing, asthma attacks and premature death $[1,2]$. So it is necessary to entrap these pollutants before they enter into the atmosphere. Air pollution reduction involves the control of particulate matter and gas. Electrostatic precipitators, cyclone separators and fabric filters are used for the former and scrubbers, incineration and carbon capture techniques are used for the later one. Out of these, scrubbers are widely used due to its ease of construction and affordability of few types of scrubbers. Based on type of working fluid, scrubbers are classified as air scrubbers, wet scrubbers, and gas scrubbers. Wet scrubbing system is very popular where one can expect satisfaction in terms of efficiency and initial investment maintenance costs $[3,4]$.
Post combustion technique is widely employed to purify petrol and diesel engine exhaust pollutants. Several experimentation results showed that, the capturing of pollutants is almost around $90 \%$ of particulate matter, when perfect set up is made. So, care should be taken in order to design the wet scrubber. In addition to engineering aspects to design the wet scrubber, cost is going to be the primary characteristic that should be kept in mind $[5,6]$.

An analogue to human body, the blood of the wet scrubber is its working fluid. Working fluids used to confine the pollutants would have greater impact over the performance of a wet type scrubber. Parameters to be considered for the selection of working fluid mainly depend upon availability and its hardness. The most common working fluid used in scrubber is bore or ground water. In addition to this, lime water is widely employed to catch the pollutants. Base can easily blend with acid solution. This is the reason why nowadays in industries, lime water is used as working fluid in wet scrubbers as blending of lime with water reduces the hardness of water [7,8]. Using working fluids as liquids has an additional advantage that they drops greatly the exhaust emissions temperature [9].

The effectiveness of wet scrubber by closely acquainting the gas stream with working liquid stream. Tubes, weirs and spraying nozzles are widely recruited to distribute the working liquids in wet scrubbers. The need to be fine enough to scrub the pollutants. Impaction, diffusion, direct interception and electrostatic attraction are the four mechanisms to collect the particulate matter in wet scrubbers. Several experiments are conducted to know which mechanism has more impact over the collection of solid pollutants. Results revealed that, the geometric mean diameter of aerosol particle $1.0 \mu \mathrm{m}$ in the diffusion-dominant region increased, whereas it decreases in the impactiondominant region [10].

Bashir Ahmed Danzomo et al. [11] developed a analytical method to improve the particle removal efficiency. They have focused to catch the particulate matter from cement industry whose diameter are $1 \mu \mathrm{m}, 5 \mu \mathrm{m}$ and $10 \mu \mathrm{m}$ and sprayed with droplet sizes of $500 \mu \mathrm{m}, 1000 \mu \mathrm{m}, 1500 \mu \mathrm{m}$ and $2000 \mu \mathrm{m}$ with a wet scrubbing system. Results revealed that the maximum collection efficiency could be with $500 \mu \mathrm{m}$ sized droplets to collect $5 \mu \mathrm{m}$ and $10 \mu \mathrm{m}$ dust particles. 
Seymour Calvert [12] investigated the scrubber capability for the collection of submicron particles. In his investigation, he considered the collection of particles is by diffusion type mechanism for several scrubber types namely venture, plate and packed column spraying tower and established a new relationship between particle cut diameter and scrubber pressure drop.

The flow arrangement to intimately contact the emissions with liquid medium are of two types. One is concurrent and counter current. The later one technique is extensively adopted due to the disadvantage of pressure drop with the former one. H. Krockta et al. [13] reported the selection parameters to fabricate a wet scrubber. They have suggested to consider economic factors, environmental factors, engineering factors in order to design an effective wet scrubber and reported the information required to specify wet Scrubber. In addition to these, they have presented the information required for scrubber at the time of operation and the information for maintenance of a scrubber.

The blood of the wet scrubber is working fluid whereas the heart is its packing material. It is a kind of surface which makes gas stream and liquid stream interacts. The commonly used packing materials are pall ring, intalox metal, berl saddle, tellerette, tri-packs and raschig ring. Initially these packings are made up of stoneware, porcelain or metal but presently they are fabricated with high-density thermo-plastics. The parameters associated in selecting a packing material are its cost, resistance to corrosion, pressure drops in chamber, specific area covered, minimum structural strength and design flexibility $[14,15]$. Nowadays, wire mesh, fiber bed and baffle type mist eliminators are popular and each type has its pros and cons. The main disadvantage of wire mesh type and fiber bed type are clogging of pollutants, whereas the baffle type mist eliminator Could not remove droplets smaller than $3 \mathrm{~mm}$ in diameter [16]. The present work is an attempt, to fabricate a new ball mesh type mist eliminator for pollution control. A new method has been employed to check whether the ball mesh type mist eliminator is worthy or not.

\section{MAterials ANd Methods}

A waste air cooler body has taken and its three sides are covered with single glass fiber reinforced polyester layer and remaining side is fastened with a transparent door to visualize the trapping of pollutants inside the scrubber. Fan along with duct, transport (push or pull) exhaust gases through ducts to and from the scrubber. A heavy duty fan with a speed of $1350 \mathrm{rpm}$ and power supply $78 \mathrm{~W}$, has been used to escape partially purified gases. Abrasion and corrosion are common problems of chimneys. Abrasion is generally more severe on ductwork leading into the scrubber, while corrosion affects ductwork leaving the scrubber. Duct is made up of thick aluminum sheet upon which single glass fibre reinforced plastic layer has been applied to prevent both abrasion and corrosion as shown in Figure 1(a). Initially, a thick aluminum sheet with required dimension is taken and then 12 inches height and 14 inches diameter cylinder has made. This cylinder is joined with truncated cone shaped aluminum sheet of smaller diameter
14 inches and bigger diameter 24 inches and then single FRP layer has applied. This chimney has fixed to the main body of scrubber and then exhaust fan has fixed inside the chimney.

A perforated tube liquid distributor is made up of a cast iron pipe with a diameter 0.5 inches is bended in a circular form by using tube bender and welded the edges to produce smooth circle shape. After that holes are made by using drilling machine for placing the studs, the studs are welded by using gas welding process. The schematic of a nozzle having diameter of $1 \mathrm{~mm}$ with 3 ports, which are attached to the studs, is shown in Figure 1(b). A total of 24 nozzles are fixed to the sprinkler and tested as shown in Figure 1(c). Packing media is vital portion of body where the scrubbing mechanism takes place. Packing media is shown in Figure 1(d), made up of rectangular mild steel mesh of $22 \times 22 \times 12$ inches, is filled with PVC balls of different diameters such as $2.5 \mathrm{~cm}, 5 \mathrm{~cm}$ and $10 \mathrm{~cm}$.

Precise assembly ensures no leakage of both working fluid and flue gases which in turn results for greater efficiency. The chimney with fan, is attached at the top surface of the body by means of single glass fibre reinforced polyester layer. Sprinkler having two pipe ends, one end is closed another end is connected to water inlet. It is fixed inside the body at top portion, with support of pipe. Packing media is held inside the body at a height of 13 inches from bottom surface with the help of clamps. A transparent fibre plate as a door is fastened on front side of the body, supported with hinges. A pipe of diameter $6.35 \mathrm{~cm}$ and $275 \mathrm{~cm}$ in length is screwed between four stroke diesel engine exhaust pipe and inlet pipe to the body to pass the exhaust gases into the scrubber

$100 \mathrm{~L}$ of ground water is taken in container. The water pumped to the sprinkler by means of $1 \mathrm{hp}$ motor with delivery rate of 2000 liters per hour. The sprinkler sprinkles the water with fine amount of spray. When the exhaust gases are entered in to the scrubber the water absorbs the pollutants in the gas. The drain water is re-circulated by using immiscible pump with $0.5 \mathrm{hp}$ motor. The sample of drain water is taken for every twenty minutes of time interval for testing the changed $\mathrm{PH}$ value with a digital $\mathrm{PH}$ meter.

TABLE I.

Pve Balls And Working Fluids Used To Purify The SMOKe OF STATIONARY FOUR STROKE DIESEL ENGINE

\begin{tabular}{|c|c|c|r|}
\hline $\begin{array}{c}\text { Diameter of the } \\
\text { PVC ball }(\mathrm{cm})\end{array}$ & $\begin{array}{c}\text { Number of } \\
\text { balls used }\end{array}$ & $\begin{array}{c}\text { Workin } \\
\text { g fluid } \\
\text { Ground } \\
\text { water }\end{array}$ & $\begin{array}{r}\mathrm{PH} \\
\text { Value }\end{array}$ \\
\hline 10 & 130 & $\begin{array}{c}\text { Ground } \\
\text { water }\end{array}$ & 8.7 \\
\hline 5 & 500 & $\begin{array}{c}\text { Ground } \\
\text { water }\end{array}$ & 8.7 \\
\hline 2.5 & 1300 & $\begin{array}{c}\text { Lime } \\
\text { water }\end{array}$ & 12.3 \\
\hline 2.5 & 1300 & & \\
\hline
\end{tabular}

\section{RESUlts AND Discussion}

$100 \mathrm{~L}$ of ground water whose concentration is $1108 \mathrm{mg} / \mathrm{L}$, used as working fluid and continuously re-circulated for 100 minutes. At the end of experimentation, the amount of water 

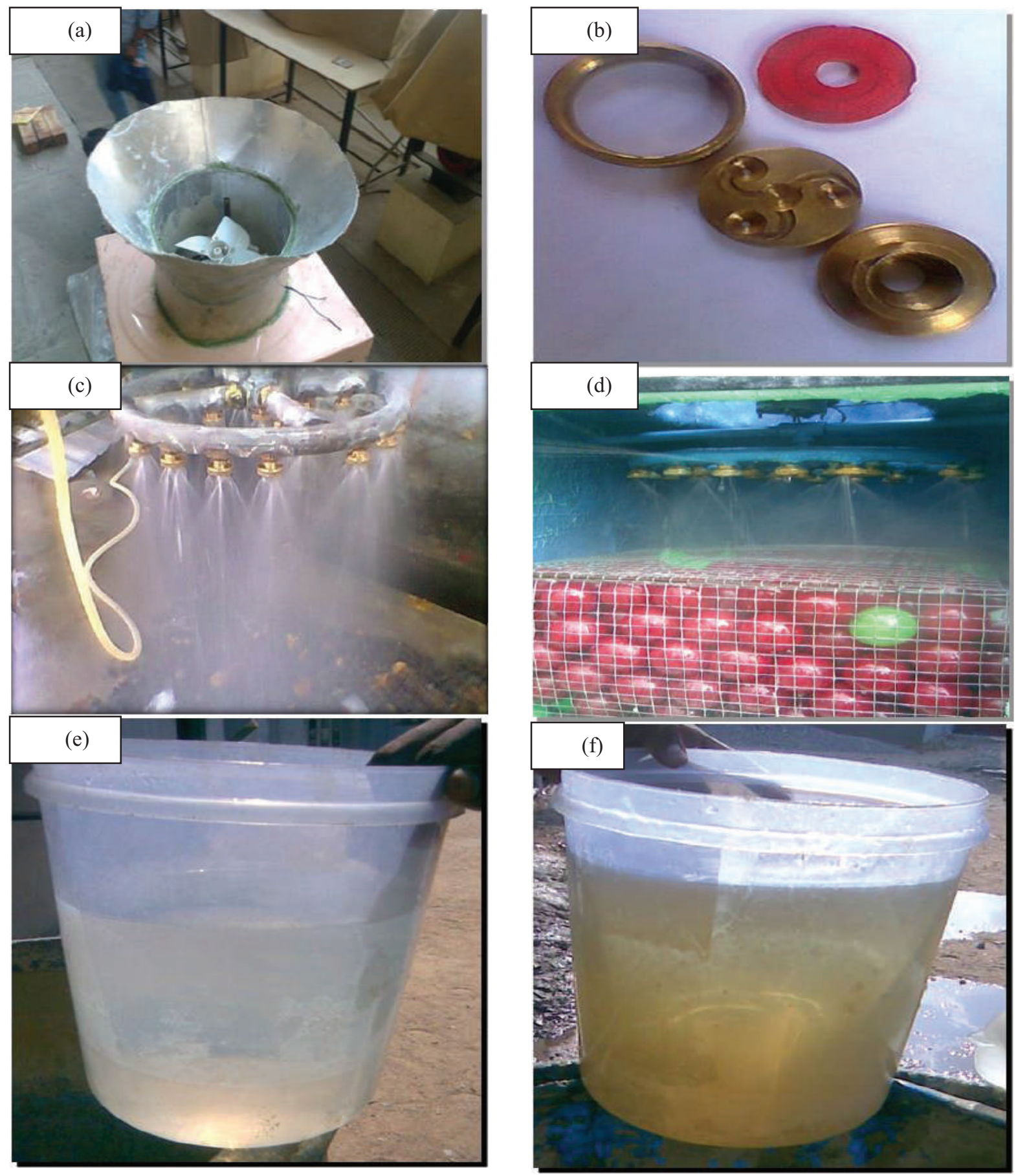

Figure 1. (a) $1 \mathrm{~mm}$ diameter nozzles with 3-ports; (b) $1 \mathrm{~mm}$ diameter nozzles with 3-ports; (c) testing the sprinkler; (d) packing media of the scrubber ; (e) water before experimentation; (f) water after experimentation. 
left is only 65 litres which means 35 litres of water was evaporated. Figures 1(e) \& 1(f) clearly indicates change in colour of water before and after experimentation.

The sample of drain water is taken for every five minutes of time interval for testing of change in $\mathrm{PH}$ value of water with a digital meter. Bar graph is plotted between $\mathrm{PH}$ value vs time interval are shown in Figures from 2 to 5 . Results $\mathrm{CO}_{2}+\mathrm{H}_{2} \mathrm{O} \rightarrow \mathrm{H}_{2} \mathrm{CO}_{3}$

When $100 \mathrm{~L}$ of lime water (PH Value=12.3) were sprinkled and re-circulated for 100 minutes, then $\mathrm{PH}$ value of the final sample found to be 8.7 and the aqueous solution found to be calcium bicarbonate. Very less, almost no solid pollutants are visible to the naked eye, as the carbon dioxide percent by volume in exhaust is much higher than the other constituents, the collected solution found to be calcium bicarbonate [17].

$$
\mathrm{CaCO}_{3}+\mathrm{H} 2 \mathrm{O}+\mathrm{CO}_{2} \rightarrow \mathrm{Ca}(\mathrm{HCO} 3)_{2}
$$

TABLE II Ph VALues With Respect To Time

\begin{tabular}{|c|c|c|c|c|c|c|c|}
\hline & & \multicolumn{6}{|c|}{ PH values - Time in minutes } \\
\hline $\begin{array}{c}\text { Ball } \\
\text { Dia.(cm) }\end{array}$ & Fluid & 0 & 20 & 40 & 60 & 80 & 100 \\
\hline 10 & Water & 8.7 & 8.2 & 7.4 & 7.1 & 6.8 & 6.5 \\
\hline 5 & Water & 8.7 & 8.2 & 7.8 & 7.4 & 7.1 & 6.8 \\
\hline 2.5 & Water & 8.7 & 8.3 & 7.9 & 7.7 & 7.3 & 7.1 \\
\hline 2.5 & $\begin{array}{c}\text { Lime } \\
\text { water }\end{array}$ & 12.3 & 12 & 11.6 & 10.5 & 8.7 & 8.1 \\
& & & & & & \\
\hline
\end{tabular}

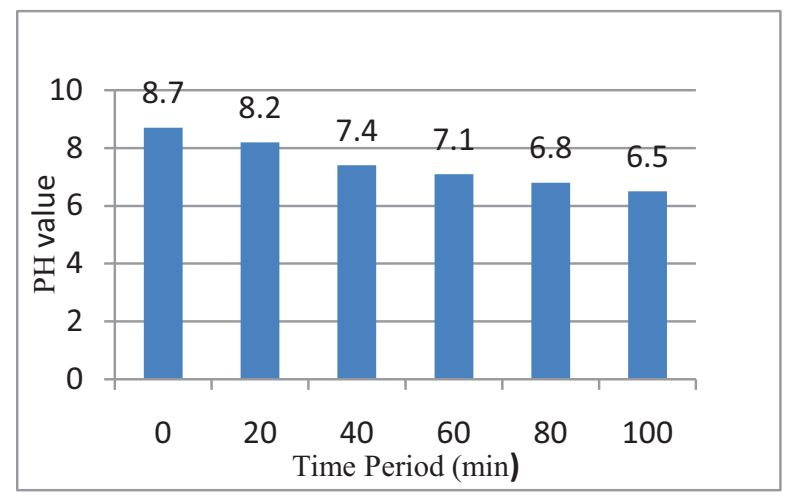

Figure 2. PVC Ball diameter 10cm-ground water. indicated that, the gradual decrease in $\mathrm{PH}$ value with respect to time. It is evident from the graph, acidity of water is increased non linearly with respected to time. The samples were tested and found that final sample is diluted carbonic acid. When the carbon dioxide dissolves in water it exists in chemical equilibrium by producing carbonic acid.

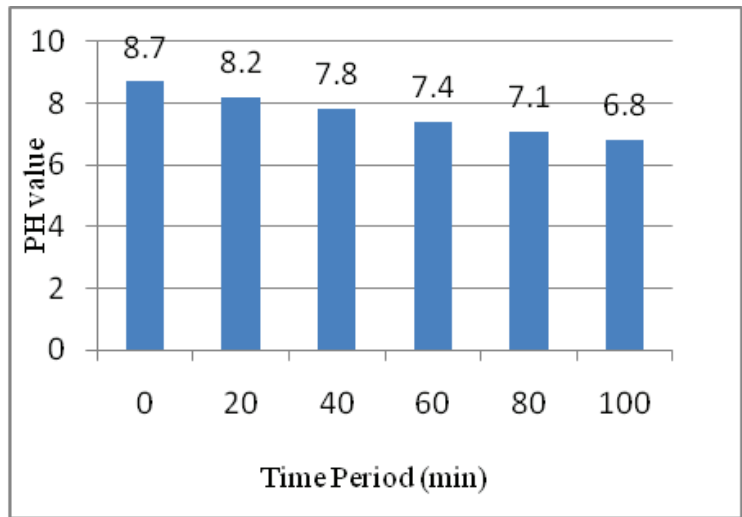

Figure 3. Diameter of the ball $5 \mathrm{~cm}$-ground water.

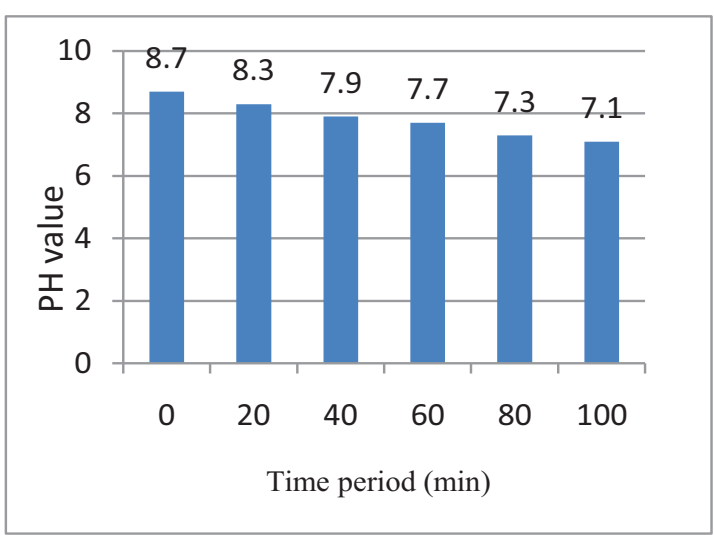

Figure 4. Diameter of the ball $2.5 \mathrm{~cm}$-ground water. 


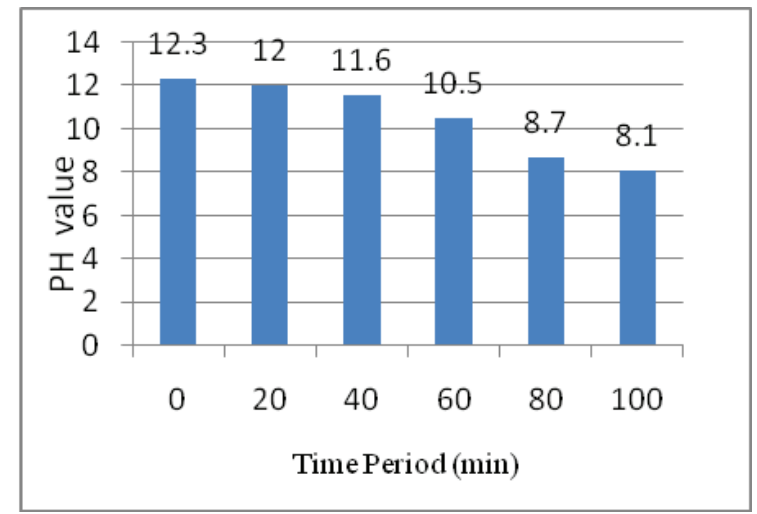

Figure 5. Diameter of the ball $2.5 \mathrm{~cm}$-Lime water

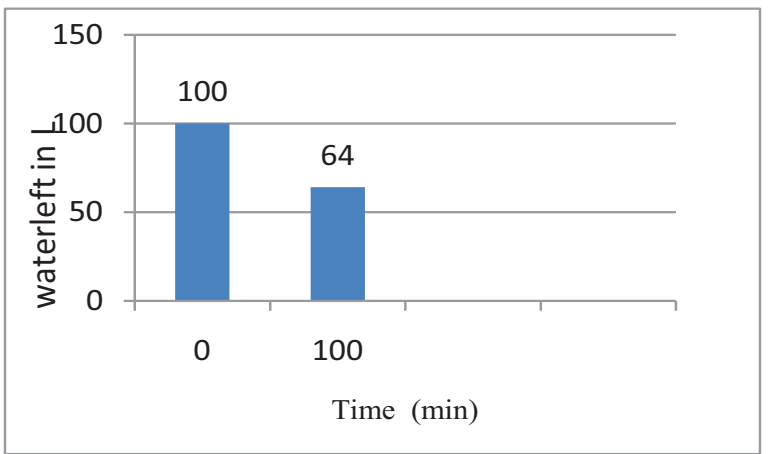

Figure 6. Water left in lit after 100 minutes of circulation

\section{Conclusions}

Though wide variety of scrubbers are available both gas \& solid pollutants and working fluid mixing phase i.e., packing media going to play vital role in all types of wet scrubbers. The main problem with few traditional mist eliminators is to replacing them every time when they gets clogged. Major conclusions drawn from the study are as follows:

I. Body set up made up of glass fabric reinforced plastics for purifying exhaust, where the temperatures raises up to $350^{\circ} \mathrm{C}$ can be promising.

II. New Ball-Mesh can be successfully used as a packing material.

III. Ball diameter is going to effect the exhaust gas scrubbing.

IV. The performance of wet scrubbers can be evaluated by means of checking the PH values-this method employed prosperously.

$\mathrm{V}$. When lime water is used as a working fluid, the samples collected, even the final sample collected was not a milky one and hence confirms again that most of diesel engine exhaust's composition is carbon dioxide.

\section{REFERENCES}

[1] Helena Ribeiro Interactions: Energy/EnvironmentFossil Fuel Energy Impacts On Health encyclopedia of life support systems (ELOSS).
[2] A.G.Chmielewski Interactions: Energy / Environment Environmental Effects Of Fossil Fuel Combustion" Encyclopedia of life support systems (ELOSS).

[3] Bethea, R. M. Air Pollution Control Technology: An Engineering Analysis Point of View. New York: Van Nostrand Reinhold 1978.

[4] H. Tejima, K. Nakazato, I. Nakagawa, M. Nishigaki "PCDDs, PCDFs Emission Control By Dry Scrubbing System" Volume 20, Issues 10-12, 1990, Pages 18991905.

[5] Gauravkhandelwal, Ishnathjha, Amitmandal, Hari Singh Use of Scrubber in Petrol and Diesel Engines Vol. 2 Issue 1 January 2013, International Journal of Latest Trends in Engineering and Technology (IJLTET).

[6] Daniel Mussatti , Paula Hemmer Wet Scrubbers for Particulate Matter - US Environmental Protection Agency. EPA/452/B-02-001.

[7] A. Seidell, W. F. Linke, Van Nostrand Solubility of Inorganic and Metalorganic Compounds - A Compilation of Solubility Data from the Periodical Literature.

[8] Ronald Reed The Nature and Making of Parchment. Elmets press, 1st edition 1975.

[9] Makkinejad N. Temperature Profile in Countercurrent/concurrent Spray Towers International Journal of Heat and Mass Transfer. 44: 429-442.

[10] H. T. Kim,C. H. Jung,S. N. Oh, K. W. Lee Particle Removal Efficiency of Gravitational Wet Scrubber Considering Diffusion, Interception, and Impaction Environmental Engineering Science Volume 18, Number 2, 2001 Mary Ann Liebert, Inc.

[11] Bashir Ahmed Danzomo, Momoh-Jimoh E. Salami SaniJibrin,Md. R. Khan and Iskandar M. Nor Performance Evaluation Of Wet Scrubber System For Industrial Air Pollution Control ARPN Journal of Engineering and Applied Sciences Vol. 7, No. 12, December 2012

[12] Seymour Calvert Engineering Design of Fine Particle Scrubbers Journal of the Air Pollution Control Association October 1974 Volume 24, No. 10.

[13] H. Krockta\& R.L. Lucas Information Required for the Selection and Performance Evaluation of Wet Scrubbers Journal of the Air Pollution Control Association Volume 22, No. 6 June 1972 Taylor and Francis.

[14] McIlvaine Company. 1974. The Wet Scrubber Handbook. Northbrook, IL: McIlvaine Company.

[15] Richards, J. R. 1995. Control of Particulate Emissions (APTI Course 413). U.S. Environmental Protection Agency.

[16] Encyclopedia of Chemical engineering equipment Mist Eliminators.

[17] Martin A. Elliott, Gerge J. Nebel And Fred G. Rounds "The Composition of Exhaust Gases from Diesel, Gasoline and Propane Powered Motor Coaches" Journal of the Air Pollution Control 